\title{
OPTIMIZING THE CEATIVE BUSINESS INDUSTRY OF WOOD-WASTE CRAFT PRODUCTS
}

\author{
Ulfa Nurhayani, Andri Zainal* \\ Accounting Education Department, Faculty of Economics, Universitas Negeri Medan, Medan, Indonesia \\ "Corresponding Author: andrizainal@unimed.ac.id
}

\begin{abstract}
The implementation of activities focused on updating production and e-commerce management on "Borna" aims at resolving some of the challenges and obstacles experienced by Borna. One of them is in the production stage, where wood cutting still uses a jigsaw, making production processes longer and limiting e-commerce that still relies on social media platforms, making marketing networks and sales levels still low. The assistance program to facilitate the resolution of the problem in question was carried out at the end of August 2019, in Binjai. In addition, on the same occasion, appropriate technology assistance was also carried out by handing over a saw machine for efficiency and effectiveness in the process of cutting round, hexagonal and trapezium wood plates. As a complement in updating partner competencies, the implementation team also provides training and assistance in developing the website as one of the main e-commerce platforms to increase partner marketing and revenue. The use of e-commerce websites in expanding market share slowly but surely has made Borna products become more exposed and known and can compete with products originating from Java Island which currently dominate national and international market share.
\end{abstract}

Keywords: Craft Products; Souvenir Wood Waste; Borna; Binjai.

\section{INTRODUCTION}

The craft sector in general has relatively demonstrated its existence with actualization that synergizes intellectual capital, wisdom and local resources both from natural and waste-based sources. Craft art product development is loaded with complex technical aspects which require surveys, observations, explorations and experiments related to the design and use of materials.

The complexity in question should be a challenge for Muhammad Akhyar, an alumni of the Vocational High School of the Craft Department who lives in Binjai City, North Sumatra Province. This 20-year-old creative young man has been consistently developing a center for the production of environmentally friendly art works through the use of wood waste into sling bags, wallets, frames and paintings with the business brand "Borna". The main material of these products is dominated by wood waste with a combination of leather and plywood as additional material that forms the intact pattern of the intended sling bag (Figure 1). Both for the construction of sling bags, wallets, frames and paintings are arranged from thin pieces of wood in the form of slabs of patterns following the design of the existing design. The patterned thin slab of wood in question is then processed again to look neat which requires high level of care and carefulness to ensure the quality achievement of the resulting wooden slabs which are not only smooth and neat but also accentuates the aesthetics of the developer's idealism. The wooden pattern plates are specifically round, half round, hexagonal, trapezoidal and square.

There are several challenges and obstacles experienced by Muhammad Akhyar (hereinafter referred to as the program partner) in the production stage of this patterned wooden slab which produces one (1) sling bag with a diameter of 20$25 \mathrm{~cm}$ requiring about 30-50 pattern plates with variations in diameter from $3-10 \mathrm{~cm}$. During this time, partners use a coping saw (coping saw) which takes about 30-60 minutes to produce one pattern wooden slab with a diameter of 3$10 \mathrm{~cm}$. So to assemble various patterns of wood slabs to become a sling bag at least takes workmanship for 5-7 days. If partners receive special orders with demands for fast delivery times and / or to attend craft exhibitions both in Binjai City and Medan City, then the partner will submit (subvert) the workmanship to the local wood workshop with a waiting time of more than 3 days (depending on the amount substrate pattern of wood slabs) so that it disrupts production patterns and quality standardization according to the expectations of partners. 


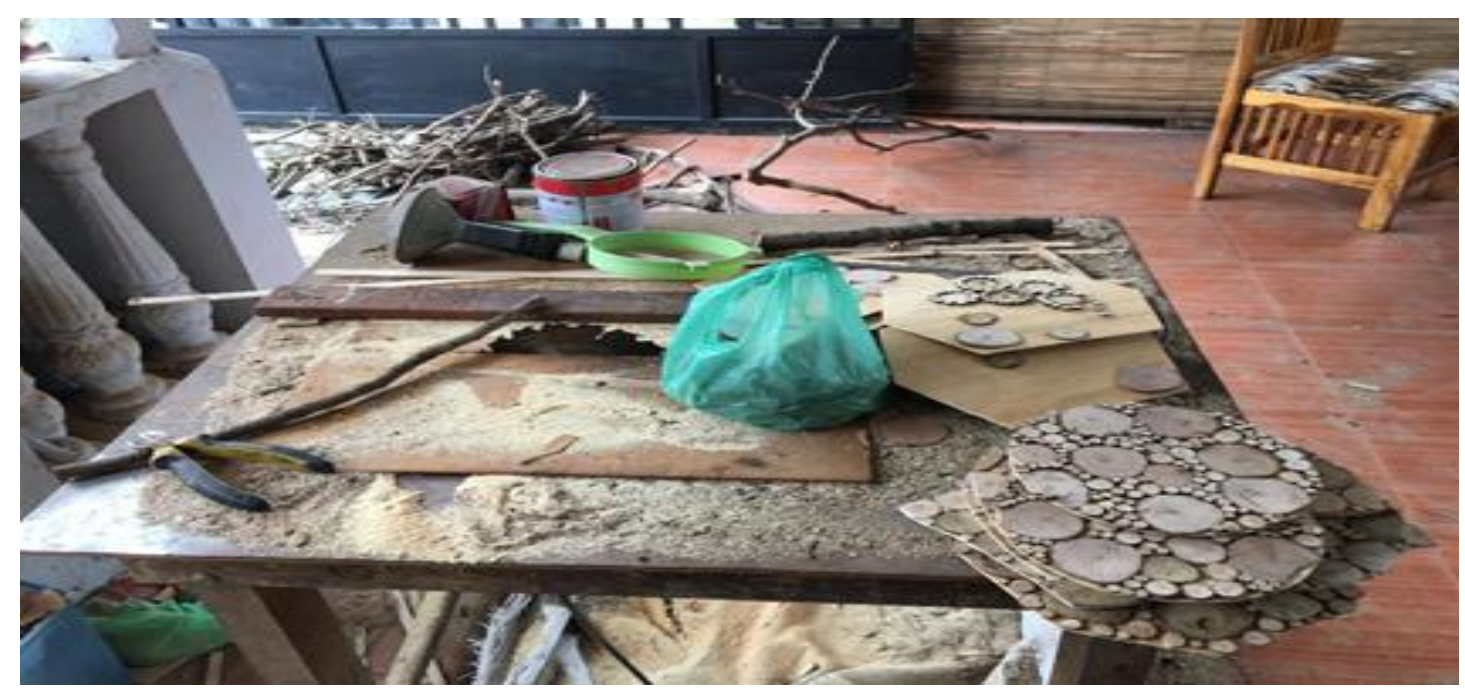

Figure 1. Timber and household waste that is the material of partner craft products.

In addition, partners have carried out online-based marketing systems with the utilization of the scope of social media platforms in the partner product marketing system which tends to be limited both in terms of quality and quantity of displays and product information as well as customer service flexibility. On the other hand, the character of craft products which emphasizes more on the aesthetic aspects requires more diverse and multi-dimensional promotional spaces for optimizing product introduction to a wider market segment with demands for more personalized product creation.

Mitra actually has accounts on several popular online buying and selling sites in Indonesia (e.g. Tokopedia, Bukalapak) but has not obtained the expected results. This is not only because the online buying and selling site has a pluralistic customer character and tends to be oriented towards household products as well because of the type of retail order (less than two items requested per order) so that it cannot cover production costs. The induction of exports of craft products to international markets produced by partners has also not been optimized but due to the limitations of e-commerce which still relies on social media platforms is also caused by mono-language display (Indonesian) with short information also hampering the acceleration of business potential from partners to scale the bigger one.

The writing of this article is intended to explain the results of the implementation of community service activities (PKM) with a focus on updating production management through the use of Miter Saw to increase the precision of production of raw materials and e-commerce with a dot com domain extension website (.com). The updating of production and marketing management in question is a major requirement for Borna MSMEs in developing the scope of business and marketing of its products in a broader direction considering that these products combine art and creativity with relatively specific market segments.

\section{MATERIALS AND METHODS OF IMPLEMENTATION}

This community service program involves 1 (one) partner, namely the Borna Business Group with Muhammad Akhyar as the business leader. Borna's business operations are currently located at Jalan Timba Perjuangan no. 15, Kelurahan Nangka, North Binjai District in Binjai City. At present, Muhammad Akhyar is assisted by 3 (three) fellow students in tertiary institutions but with limited role capacity that is only temporary production staff.

As explained in the previous segment where the priority issues that are the main issues in business management and production "Borna" are on: (1) the production chain especially in the process of producing semi-finished goods is still done manually which results in a long waiting time; and (2) the use of social media-based marketing channels that are relatively unable to optimize sales turnover. To overcome these two priority problems, the PKM implementation team consisting of: Ulfa Nurhayani, S.E., M.Sc.; Andri Zainal, Ph.D., Ak., CA .; and Haryadi, S.Kom., M.Kom. has provided assistance that focuses on increasing the capacity and quality of products and the marketing mix of products produced by the "Borna" business group. The focus of the intended improvement includes the following assistance activities:

a. Utilizing the application of appropriate technology tools that are able to accelerate the production value chain to finished goods.

In this activity, the implementation team facilitated the technical management of Borna business in the use of and the use of Elbow Saw ( more pulalrly known as Miter Saw) for the efficiency and effectiveness of the process of cutting round, hexagonal and trapezium patterned wood slabs which have become the hallmark of partner products. 
b. Development of a marketing strategy for craft products with domain expansion for independent websites.

In this activity, the implementation team carried out a dot com extension website development assistance program as one of the main e-commerce platforms of the partner business.

The mechanism of the approach to solving priority problems that have been agreed with partners is presented in Figure 2 below.

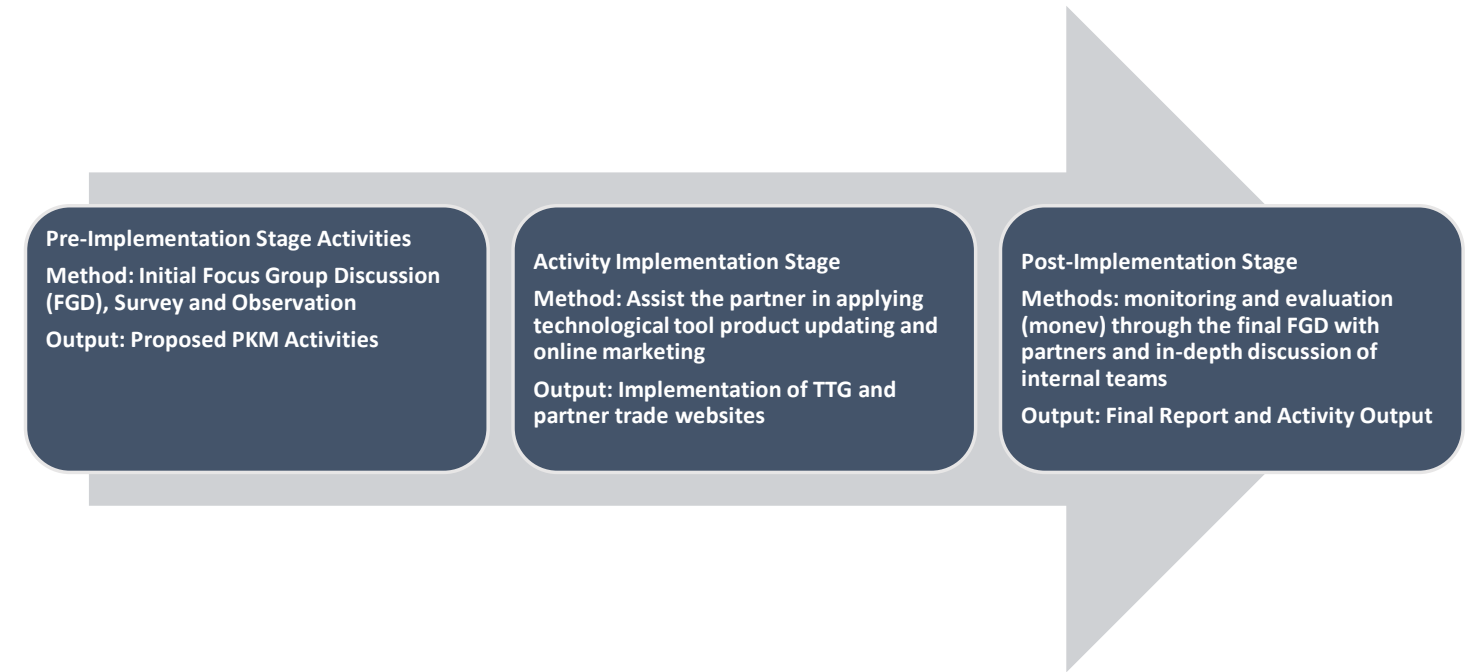

Figure 2. Approach Method for Each Stage of Activity Implementation.

\section{RESULTS AND DISCUSSION}

The implementation of the activity went well where the partners together with their colleagues were able to utilize the use of the military miter saw properly. Assistance of the intended use of the machine lasts for 1 (one) day with a duration of implementation for 3 (three) hours. During the implementation of assisting the use of the engine miter saw there was 1 (one) obstacle namely the inadequacy of electric power that was able to sustain the operation of the machine with a capacity of 1800 watts. However, this has been resolved well in the short term, where partners have collaborated with a wood cutting workshop located near the Borna production area through a "cut-and-cut" system. The wood cutting workshop in question has electrical power that is capable of sustaining the use of a miter saw machine but does not have the intended machine to cut wood in small and unique shapes so that by consigning the miter saw machine in the wood workshop provides an alternative win-win. win solution for both parties. In the future, the manager of Borna will increase the electric power in his production house so that he can more freely use the machine independently.

Another outcome is the development of dot com domain-based website development. In this activity, the implementation team provides technical assistance and guidance that enables partners to manage their marketing channels based on internet networks more flexibly and optimally. Utilization of this website is crucial given that it can complement the marketing platform that has been used by Borna so far based on social media (Facebook and Instagram) but with more varied content and menu extensions. The interface of the Borna website (www.bornabag.com) can be seen in Figure 3 below. 

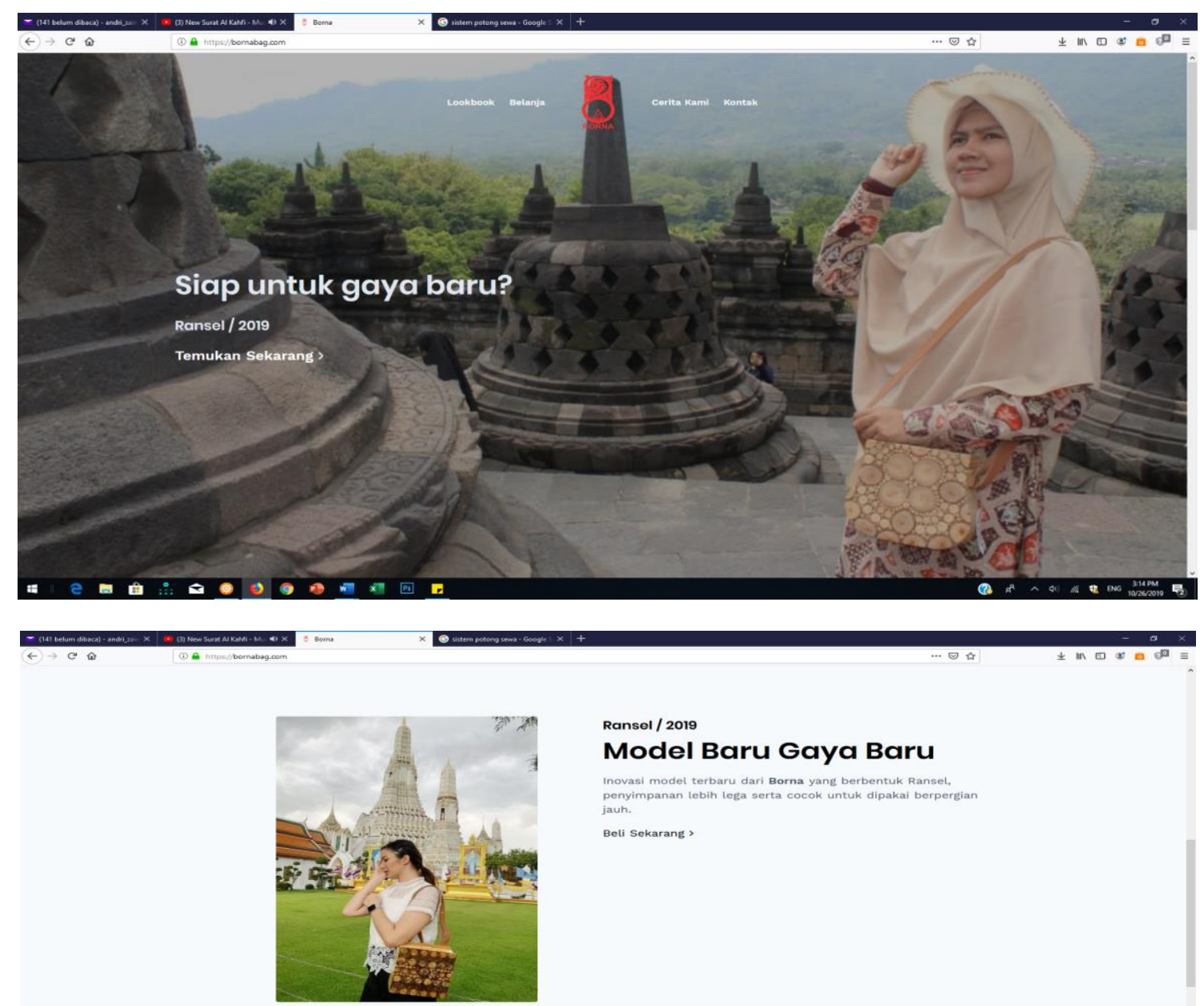

Ransel / 2019

Model Baru Gaya Baru

inovasi model terbaru dari Borna yane berbentuk Ransel,
penyimpanan tebih lega serta cocok untuk dipakai berpergian

Beli Sekarang >

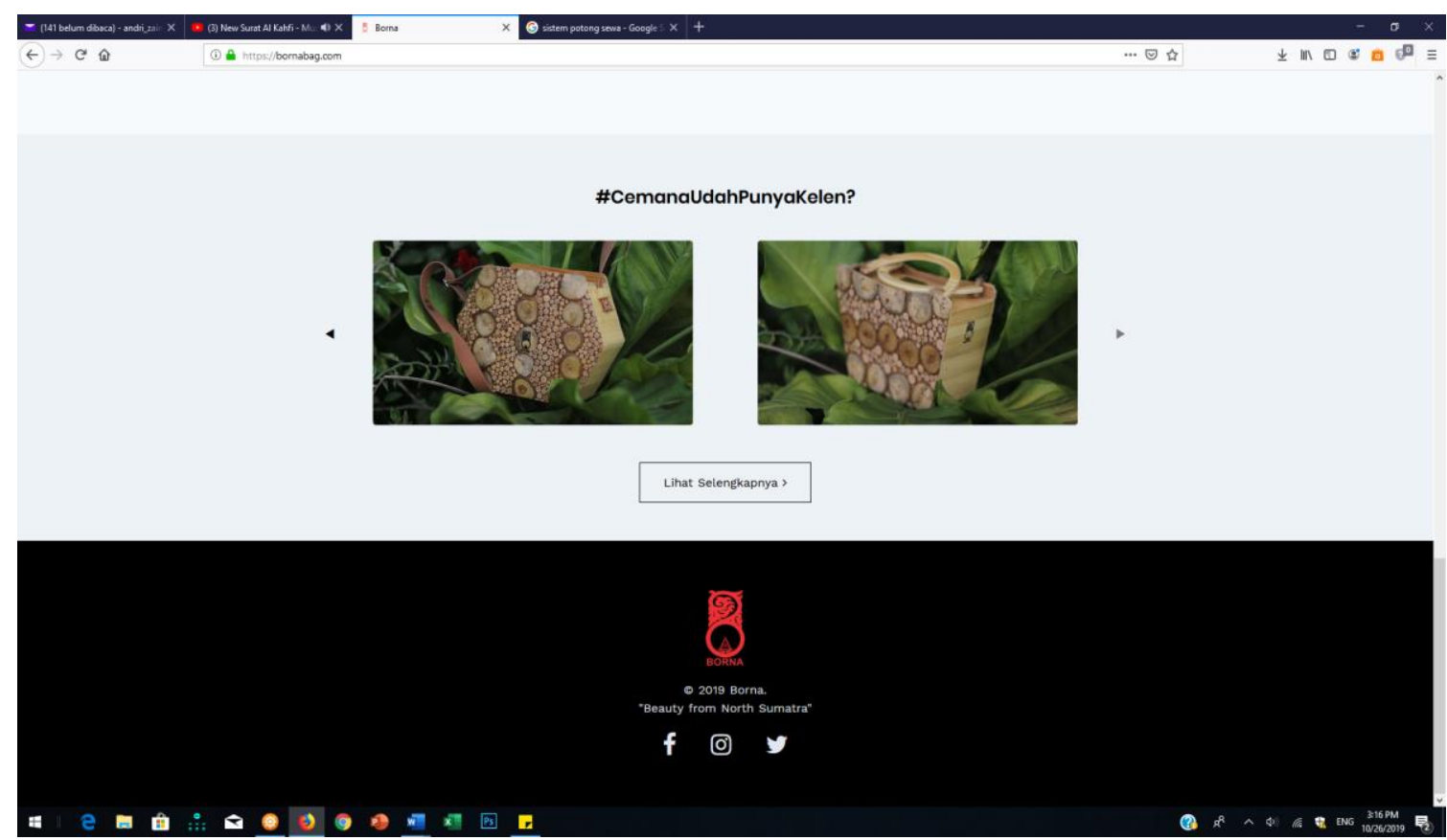

Figure 3. Display of the web page www.bornabag.com 


\section{CONCLUSION}

This community service activity aimed at increasing business capacity through production management and marketing management assistance of the Borna Business Group located in the city of Binjai in North Sumatra Province proceeded smoothly and according to the planned plan. The fostered partner in this case is the manager of a wood waste-based craft product driven by M. Akhyar to feel a significant benefit from the Community Service activities that have been carried out by the implementing team from UNIMED.

In the future, there is one important aspect to emphasize, namely regarding product diversification through optimizing the use of machines for the creation of patterns and shapes that can support the identity of the products that have been produced by Borna. Product diversification in question is related to product design updates that keep pace with the times to be able to bring business partners to a better direction in accordance with the demands of the light souvenir business in the modern era.

\section{ACKNOWLEDGMENT}

The organizing team of the PKM activity and the author of the article " Optimizing The Ceative Business Industry Of Wood-Waste Craft Products" thanked the facilitation of funding that has been provided by the Institute of Research and Community Service at Medan State University (LPPM UNIMED) in the form of a Community Service Award competition grant in the State University Operational Assistance scheme (BOPTN) 2019 funding year. 